\title{
Kapitalismi kulttuurissamme
}

\section{Jussi Ojajärvi, Erkki Sevänen \& Liisa Steinby (toim.): Kirjallisuus nykykapitalismissa: Suomalaisen kirjallisuuden ja kulttuurin näkökulma. Helsinki: SKS, 2018, 454 S.}

Kapitalismi, markkinat ja uusliberalismi ovat olleet toistuvia 2000-luvun teemoja niin kotimaisessa kirjallisuudessa kuin siitä tehdyssä tutkimuksessakin, mutta aihepiirin ympärille kietoutuvia artikkelikokoelmia ei pahemmin ole julkaistu. Tässä mielessä Jussi Ojajärven, Erkki Seväsen ja Liisa Steinbyn toimittama artikkelikokoelma Kirjallisuus nykykapitalismissa tekee näkyväksi yhden nykykirjallisuudentutkimuksemme syvistä - mutta toisinaan huomaamattomista - virroista.

Kokoelman "suurena kertomuksena" on uusliberalistiseksi nimetty kapitalismin vaihe. Kirja lupaa tulkintoja siitä, "miten suomalainen kirjallisuus ja sen lähialueet - teatteri ja elokuva - käsittelevät nykyistä markkinakapitalismia ja millaista kritiikkiä niiden piirissä syntyy.” Tämän lupauksen kokoelma pitää, ja juuri kirjallisuudessa esiintyvä kapitalismikritiikki onkin yksi teoksen keskeisistä juonteista.

Kokoelman avaa laaja johdantoluku, jossa esitellään kapitalismin käsitettä, kulttuurin- ja kirjallisuudentutkimuksen perinteisiä tapoja lähestyä kapitalismia ja kotimaista kapitalismikriittistä tutkimusta. Johdanto on varmasti käyttökelpoinen katsaus sellaisille tutkijoille ja opiskelijoille, joille kapitalismikriittinen näkökulma kirjallisuuden- ja kulttuurintutkimukseen ei ole kovinkaan tuttu. Siinä esitellään tiiviisti lähinnä marxilaisesta perinteestä ammentavan tutkimuksen tärkeitä käsitteitä, kuten reifikaatio, tavaroituminen, totaliteetti ja vieraantuminen sekä teesit subjektin fragmentoitumisesta ja taiteen ja talouden välisten rajojen hälventymisestä. Samalla johdatellaan olennaisten tutkimuslähteiden ja teoreetikoiden äärelle. Keskeisistä tutkimusperinteistä ja käsitteistä puuttumaan jää oikeastaan hieman yllättäen vain ideologiakritiikki, mutta ehkä sen pois jättäminen heijastelee kokoelmassa sovellettua käsitteistöä.

Johdantoa seuraa joukko katsaustyyppisiä artikkeleita, joissa Erkki Sevänen ja Voitto Ruohonen käyvät läpi niin kapitalismin, kirjallisuusinstituutioiden kuin julkisuudenkin historiallista kehitystä. Ruohonen esittelee myös kulttuurijournalismin muutoksia Helsingin Sanomissa. Seväsen ote suosii etenkin periodisointeja ja kategorisointeja.

Kotimaisen kirjallisuuden sisällöistä kiinnostuneille lukijoille kokoelma saattaa alkaa turhan verkkaisesti, mutta jos kiinnostuksena on kapitalismi ja sen suhde kulttuurisiin instituutioihin, alku toimii selväsanaisena katsauksena viime vuosisatojen kehitykseen. 
Yli 400-sivuisen järkälekokoelman toinen puolikas taas tarjoaa tulkintoja nykykirjallisuudesta ja sen lähilajeista. Liisa Steinby ja Mikko Tirronen vertailevat Don DeLillon ja Kari Hotakaisen romaanien subjektiviteetteja, Riitta Pohjola-Skarp ja Hanna Suutela keskittyvät työn kuvauksiin kotimaisissa nykynäytelmissä, Sanna Karkulehto ja Ilmari Leppihalme erittelevät seksuaalisuuden ja kaupallisuuden risteyskohtia nykykirjallisuudessa, ja Elina Arminen tutkii kirjallisuusmaailman satirisointeja. Marxilaisen kirjallisuudentutkimuksen grand old manin, Fredric Jamesonin, ennen julkaisematon artikkeli puolestaan ruotii Hannu Raittilan Pamisoksen purkausta, kun taas Andrew Nestingenin artikkeli tulkitsee Aki Kaurismäen Le Havre -elokuvaa allegorisena utopiana ja kolonialismin jälkioireena. Teoksen päättää Kristiina Malmion moninäkökulmainen analyysi kapitalismin ja suomenruotsalaisen kirjallisuuden suhteista.

Vaikka empiiristen artikkelien tulokulmat vaihtelevatkin, niitä myös yhdistää yllättävän moni asia. Metodologisesti ne pohjaavat ennen kaikkea teosten kontekstualisoivalle lähiluvulle, jossa lukijana on lähes poikkeuksetta tutkija itse. Omia käsitteitä tai teorioita ei kuitenkaan pahemmin kehitellä. Artikkeleissa ensisijaisesti sovelletaan olemassa olevaa - pitkälti kansainvälistä käsitteistöä ja sen mukaisia teoria-apparaatteja - suomalaiseen aineistoon. Analyysin kohteena ovat usein henkilöhahmot ja heidän väliset suhteensa; miljöiden, rakenteiden, kielenkäytön ja poetiikan kommentointi jää vähemmälle. Kohdetekstejä tulkitaan pääsääntöisesti myötäkarvaan, ja ne on valikoitu siksi, että niistä on löydetty kriittistä suhtautumista kapitalismiin. Oikeastaan kaikissa artikkeleissa kirjallisuuden nähdään kuvastavan, analysoivan tai parodisoivan uusliberaalia puhetapaa tai sen läpitunkemaa kokemusta milloin työelämästä, milloin ihmisyydestä, seksuaalisuudesta tai kirjallisuusmaailmasta. Näin ollen artikkelit lähestyvät kirjallisuutta ennen kaikkea nykykapitalismin kriittisenä tulkitsijana tai heijastelijana. Vaikka muutamassa luvussa esiin nouseekin kysymyksiä siitä, voisiko kirjallisuus myös tarjota vaihtoehtoja uusliberalismille tai toisaalta uusintaa ja vahvistaa kapitalismia, tällaiset tulokulmat eivät ole kokoelman ytimessä.

Lähilukuun perustuvien tekstien sekaan on upotettu Jussi Ojajärven teoreettisesti tuhti katsaus Fredric Jamesonin ajatteluun. Itseäni kiehtoi siinä etenkin totaliteetin käsitteen henkiinherättäminen ja sen pelastaminen jälkistrukturalististen kriitikoiden kynsistä. Totaliteetin käsitteellä operoitaessa pohdiskellaan sitä, miten kirjalliset tekstit voivat välähdyksenomaisesti representoida kompleksista sosiaalista ulottuvuutta, auttaa kartoittamaan kokonaisuutta muodostavia suhteita ja silloittamaan yksilollistä elettyä kokemusta yhteiskunnalliseen kokonaisuuteen. Tällainen totaliteettien kartoittaminen on Jamesonin mukaan loppumaton prosessi, ei mikään totalitaristinen viimeinen sana maailmasta.

Näistä lähtökohdista teos toimii hyvänä katsauksena siihen, miten kapitalismin ja kirjallisuuden suhteita Suomessa tällä hetkellä tutkitaan. Mieli tekisi kuitenkin rohkaista tutkijoita myös omaehtoisempaan käsitteenmuodos- 
tukseen ja vahvempiin tulkintoihin, sillä monia tekstejä leimaa jonkinlainen tulkinnallinen varovaisuus. Ehkä hieman yllättäenkin niissä vältellään vahvoja teesejä tai väitteitä. Teksteissä korostuu sekä-että-asenne, ja etenkin kriittistä etäisyyttä suhteessa tutkittavaan aineistoon vältellään. Silloinkin kun kriittisiä kysymyksiä kysytään, ne esitetään ennemmin yhtenä näkökulmana muiden joukossa ja vahvaa näkökulmallisuutta - erään kirjoittajan sanoin mustavalkoisuutta tai yksioikoisuutta - kartetaan.

Ehkä tässä mielessä artikkelien eetos toistaa Jamesonin esseen ajatusta, jonka mukaan kirjallisuuden tutkijoiden ja teoreetikoiden asiana ei ole "kertoa romaanien kirjoittajille, mitä heidän pitäisi tehdä saati mitä he voivat tai eivät voi tehdä". Neuvo on varmasti hyvä periaatteellinen ohjenuora, mutta jos sitä noudattaa liian orjallisesti, voi lopputulos olla turhankin arka. Itse jäin nimittäin kaipaamaan monelta kokoelman tekstiltä reippaampaa otetta ja halua viedä tulkintoja pidemmälle. Eihän vahvojen tulkintojen kai tarvitse tarkoittaa dogmaattista määräilyä tai tuomarointia; mikseipä sitä voisi nähdä myös tapana viedä keskustelua eteenpäin? Tällainen rohkea asenne sopisi hyvin kapitalismikritiikistä ja Jamesonista ammentavaan perinteeseen, jossa etsitään dialektisia käänteitä, eli sitä, miten negatiivinen voi muuntua positiiviseksi ja toisin päin.

Hanna Kuusela 